研究

カオスを用いた放電加工の放電点分布の解析 ${ }^{*}$

韓 福柱** 国枝 正典**

\title{
Distribution of Discharge Location in EDM Using Chaos Theory
}

\author{
Fuzhu HAN and Masanori KUNIEDA
}

\begin{abstract}
In this paper we describe the analysis of the distribution of discharge location using chaos theory in Electrical Discharge Machining (EDM). Chaos is a nonlinear phenomenon which is determined by a relatively simple rule, although it appears complicated and random. It was found that the discharge location is simply determined by the gap distribution and the debris particle distribution in spite of the complicacy and randomness of these distributions. Namely, the discharge occurs at the location where the gap is narrow and the debris density is high. Consequently, we analyzed the discharge location distribution using chaos theory and found the following: 1) the distribution of discharge location is irregular, 2) a bifurcation is observed, 3) the attractor dimension is relatively small, and 4) at least one of the Lyapunov exponents is larger than zero. By calculating the attractor dimension, we also found that there is a correlation between the attractor dimension and machining stability, that is, the higher the attractor dimension is, the greater the stability of machining is. This means the machining stability, which has not been detectable so far, can be distinguished by calculating the attractor dimension.
\end{abstract}

Key words: EDM, chaos, attractor dimension, Lyapunov exponent, distribution of discharge location

\section{1. 緒論}

放電加工において，極間における放電点の分布 は加工現象に重大な影響を及ぼしている．加工中 に放電点の集中または偏在が発生すると, 加工速 度の低下とともに加工精度も悪化する.このため, 放電加工の放電点分布の研究は非常に重要な課題 になっている. そこで, Kunieda ら ${ }^{12)}$, 小原ら ${ }^{3)}$ は分割給電法による放電位置の検出法を提案し, 極めて観察しにくい放電現象を放電位置検出によ り,パソコン上に可視化した.一方, Mohri i)らは,

* 電気加工学会全国大会(1999)にて一部発表

** 東京農工大学工学部
極間の電圧波形の立下りから放電点分布状態の予 測を試みている．放電点分布は一見ランダムで複 雑であるが, 実際に各放電位置はその時のギャッ プ分布と加工屑濃度分布などによって決められて いる，つまり，ギャップが狭い，加工屑濃度の高 い場所に放電が生じると考えられる. Kunieda ら 5)6)はこのような規則性を基に放電加工のシミュ レーションが可能であることを証明している，従 つて, 放電加工の放電点分布は複雑に見える一方 で支配する規則は比較的に簡単であると言える. このような簡単な規則が支配する複雑な現象を解 析するに当たって, 最近カオスという理論が生ま れてきた，本研究はカオスの理論を用いて，放電 点分布を解析し, 放電加工の放電点分布は実際に はカオス的な現象であることを実証するとともに， 
カオスを積極的に制御に応用する可能性を検討す る.

\section{2.カオスの概要}

カオスとは, 比較的少数の自由度しか持たない 決定論的な系であるにもかかわらず，予測不可能 で乱雑な挙動を示す状態である.つまり, 初期条 件が決まれば未来の状態が一意的に決まる決定論 的な系に生じる不安定で有界な非周期運動である。

カオスの判定方法 2) 8) としては通常，1）系の 解が不規則に振る舞うこと，2）分岐現象が存在す ること，3）系が少数自由度を持つこと，4）解の 相空間内での軌跡が不安定で, 初期值敏感性を持 つこと，などが挙げられる．上記 1) の判定に従 えば, 得られた信号が不規則振動であるか否かは, 波形を一見して明らかであるが，パワー・スペク トルが広がっているか, 或いは信号の時間相関関 数が時間軸正方向に急激に減少する傾向から不規 則な度合を判定する場合も多い.また，2）は系を 支配するパラメー夕を変化させた時，系が規則 ＼cjkstart不規則振動の間で遷移を起こすことより判定す る. 3）によれば，相空間の軌道の作る図形（アト ラクタ）の次元を求め, もしこの次元が小さけれ ば対象の系は少数自由度の系であると判定する。

ここでアトラクタとは軌道が安定した状態を意味 している.4）の軌道不安定度は近接した軌道間の 距離が長時間的に指数関数的に挔がって行くもの で,この指数（リアプノフ指数）が正であれば不 安定と判定する.

\section{3. 実験方法}

図 1 には分割給電法に基づく放電点位置検出装 置 ${ }^{122)}$ の概要を示す.コンピュータが電流センサか ら検出した四つの分割電流 $\left(i_{1}, i_{2}, i_{3}, i_{4}\right)$ を読み 込んで，放電位置を計算する，放電点位置 $(X, Y)$ の計算式を次に示す.

$$
\begin{aligned}
& X=A_{x}\left\{\left(W_{y}-W_{0 y}\right)^{2}+B_{x}\right\}\left(W_{x}-W_{0 x}\right) \\
& Y=A_{y}\left\{\left(W_{x}-W_{0 x}\right)^{2}+B_{y}\right\}\left(W_{y}-W_{0 y}\right) \\
& \text { ただし, } W_{x}=\log \frac{i_{4}}{i_{3}}, W_{y}=\log \frac{i_{2}}{i_{1}} . \text { また, } A_{x},
\end{aligned}
$$

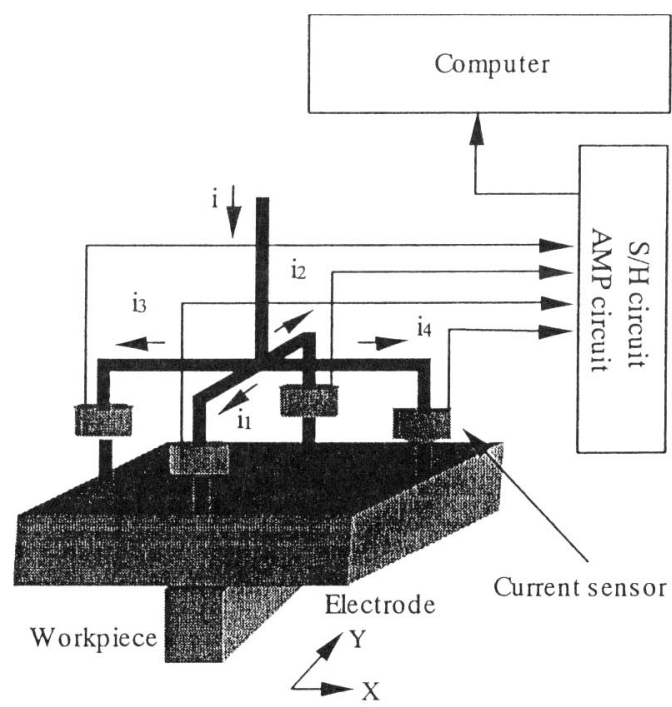

Fig. 1 Schematic diagram of discharge location detector

Table 1 Machining conditions

\begin{tabular}{|lc|c|}
\hline Open circuit voltage & $u_{i}$ & $90 \mathrm{~V}$ \\
\hline Discharge current & $i_{e}$ & $15 \mathrm{~A}$ \\
\hline Discharge duration & $t_{e}$ & $210 \mu \mathrm{s}$ \\
\hline Pulse interval & $t_{0}$ & $20,80 \mu \mathrm{s}$ \\
\hline
\end{tabular}

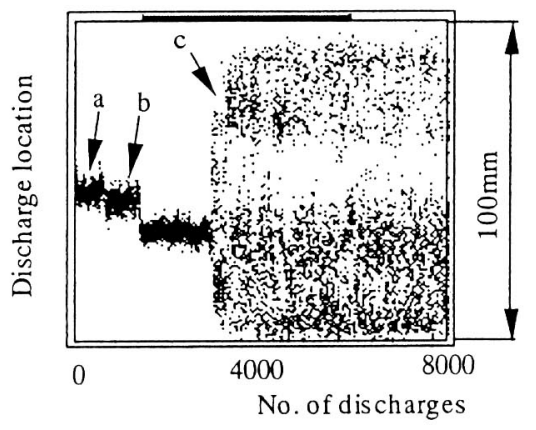

Fig. 2 Bifurcation of distribution of discharge locations

(Discharge current $15 \mathrm{~A}$, pulse duration $210 \mu \mathrm{s}$, pulse interval $20 \mu \mathrm{s}$ )

$A_{y}, \quad B_{x}, \quad B_{y}, W_{0 x}, W_{0 y}$ はキ+リブレーション

から求められる定数である2).

電極は $100 \mathrm{~mm} \times 100 \mathrm{~mm}$ のグラファイトを使った. 
ワークは偏在現象を起し易いために $10 \mathrm{~mm} \times 100 \mathrm{~mm}$ の細長手の S45C を使用した. そのため, 放電点分 布は長手方向（Y 方向）だけを考慮した. 加工条 件は表 1 に示す.

\section{4. 放電点分布の分岐現象}

不規則データを捉えた時，まず，それが実験系 への外部雑音によらず，系自身の示す不規則性で あることを示す必要がある．この一つの方法とし て，系を支配するパラメータを変化させ，系の規 則い一不規則振動の間の遷移の有無を調べる方法 がある. カオスを生じる系は, 通常, 系のパラメ 一夕を変化させると, 非力オスーカオス間の転位 を起こす.このカオスへの移り方は数種類あるが, 休止時間が $20 \mu \mathrm{s}$ と比較的に短い場合, 放電点分 布は図 2 に示す代表的な分岐現象を示した。 図 2 は安定交換分岐之言われ,一つの安定な不動点(図 2 の “a”, ) から他の安定点（図 2 の “b”）に変化 し, 系のパラメータ（加工屑濃度, 電極表面の温 度, 極間ギャップ）の変化に伴って，カオス状態 （図 2 の “c”）に到る. 図 2 の縦軸はワークの長 手方向の放電位置, 横軸は放電回数であるが，そ の放電回数の増加に伴い, 系のパラメータが変化 していると考えられる。

\section{5. 放電点分布のアトラクタ次元}

\section{1 放電点分布のアトラクタ}

放電位置の例えば X 座標の時系列データを $\left(x_{1}, x_{2}, x_{3}, \cdots, x_{k}\right)$ とすると, これらのデータより $m$ 次元の空間の中に軌道を描くには, $\boldsymbol{x}_{j}=\left(x_{j}, x_{j+1}, x_{j+2}\right.$, $\left.\cdots, x_{(j+(m-1)}\right) ，(j=1,2, \cdots, N-m+1)$ の軌跡を作ればよ い.すなわち軌道を凸次元の空間に埋込み (embedding), このmを埋込み次元とよぶ. この埋 込みの方法により，アトラクタの次元が一つの時 系列データより求められることをターケンス (F. Takens, 1981)が示した ${ }^{8)}$. このアトラクタ次元の 決め方については次節で述べる.

\section{2 放電点分布のアトラクタ次元}

アトラクタの次元はアトラクタを特徴づける重 要な量であり,この次元が小さければ, この系は 少数自由度の系として振る舞い低次元のダイナミ クスで記述できる. アトラク夕次元を求める方法

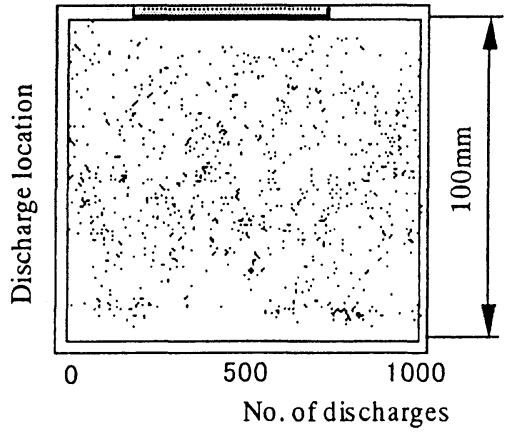

Fig. 3 Example of distribution of discharge locations

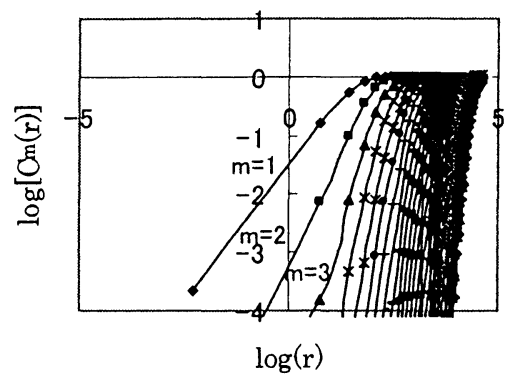

Fig. 4 Relationship between correlation integral and $\mathrm{r}$ for distribution of Fig. 3

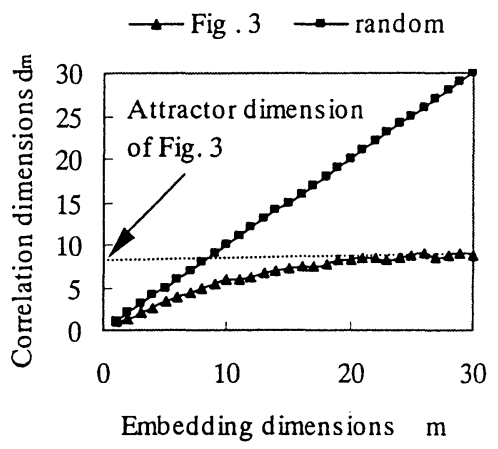

Fig. 5 Attractor dimension of distribution of Fig. 3

はいくつかあるが，本報では相関積分による相関 次元を求める方法 ${ }^{778)}$ を使用した. 5.1 節により放 電位置データから $m$ 次元空間のベクトル $\boldsymbol{x}_{j}=\left(x_{j}, x_{j+1}, x_{j+2}, \cdots, x_{(j+(m-1)}\right), \quad(j=1,2, \cdots, N-m+1)$ を構成する. そして, 任意の二つのべクトルの距 離 $/ \boldsymbol{x}_{i}-\boldsymbol{x}_{j} /$ を求め次の計算を行う. 


$$
\mathrm{C}_{\text {m }}(\mathrm{r})=\frac{1}{N^{2}} \sum_{i, j}^{N} \theta\left(r-\left|\boldsymbol{x}_{i}-\boldsymbol{x}_{j}\right|\right)
$$

ここで $\theta$ はへビサイドの階段関数で $\theta(x)=0$ $(x<0), \quad \theta(x)=1(x \geqq 0)$ である. $\mathrm{C}_{\mathrm{n}}(\mathrm{r})$ は相関積分

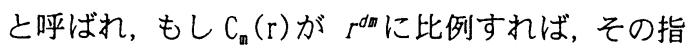
数 d,は相関次元を与える.

図 3,4,5 は放電点分布のアトラクタの相関次元 を求めた一例を示す. 図 3 に示すような放電位置 データから次元ベクトル $\boldsymbol{x}_{i}$ を作る．（1）式を用 いて $C_{n}(r)$ を $r$ の関数として求め, 位相空間上の 距離 $r$ に対して求められた相関積分 $C_{m}(r)$ の $10 \mathrm{~g}$ をとったものを図 4 に示す. 相関次元 $d_{\square}$ は図 4 の 傾きで近似的に与えられる. 図 4 から求めた相関 次元 $d_{m}$ と埋込み次元 $m$ の関係を図 5 に示す. 図 5 に示すように埋込み次元 $m$ を 21 以上大きくして も相関次元 $d_{m}$ が 7.6 で留まるので, 図 3 の放電点 分布は 8 次元程度のアトラクタ内の運動として記 述される.この結果は，一目乱雑に見える放電点 分布データが低次元のダイナミクスで記述でき, カオスであることを示している. 時系列データが ランダムプロセスに従っている場合には，データ が多次元状態空間内に密に分布するため, 相関次 元は埋込み次元と一致する（図 5). 従って, 放電 点分布は多次元状態空間においてランダムプロセ スと異なる性質をもっている.

\section{6. 放電点分布のリアブノフ指数}

カオスの一つの大きな特徵は, 相空間の近接し た軌道が時間の発展とともに指数関数的に離れて いくことである，この近接した軌道の離れ方を表 わす量としてリアプノフ指数 (lyapunov exponent）入がある.リアプノフ指数は次のように 求める 9)(0)(11).

軌道 $\mathbf{X}(t)=\left(x_{1}(t), x_{2}(t), \cdots, x_{m}(t)\right)$ は $m$ 次元微

分方程式 $\dot{\mathrm{x}}(\mathrm{t})=\boldsymbol{F}(\mathrm{x})=\left(F_{1}(\mathrm{x}), F_{2}(\mathrm{x}), \cdots\right.$, $\left.F_{a}(\mathrm{X})\right)$ 解とする. 軌道 $\mathrm{X}(\mathrm{t})$ に対して, 初期点 $\mathrm{x}(0)$ から $\delta \mathrm{x}(0)$ だけわずかに離れた点から始 まる近接軌道 $\mathrm{x}(\mathrm{t})+\delta \mathrm{x}(\mathrm{t})$ を考える. $\delta \mathbf{x}(\mathrm{t})$ の時間発展はヤコビ行列 $\mathrm{J}=\frac{\partial\left(F_{1}, F_{2}, \cdots, F_{m}\right)}{\partial\left(\mathrm{x}_{1}, \mathrm{x}_{2}, \cdots, \mathrm{x}_{\mathrm{m}}\right)}$ を用い

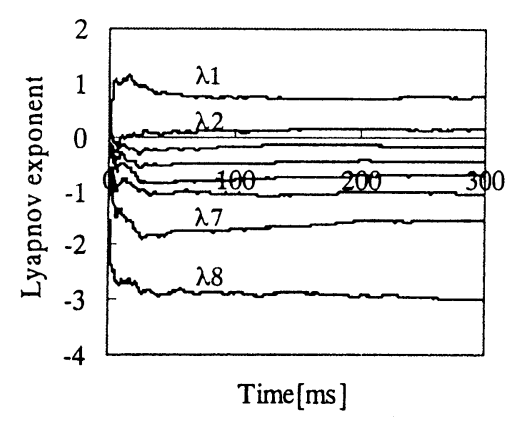

Fig. 6 Ly apunov exponents of distribution of Fig. 3

て, $\delta \dot{\mathbf{x}}(\mathrm{t})=\mathrm{J} \delta \mathbf{x}(\mathrm{t})$ に従うが, これを時間 $t$ にわたって積分すると行列 $\mathrm{L}(\mathrm{x}(0), t)$ を用いて

$$
\delta \mathbf{x}(\mathrm{t})=\mathrm{L}(\mathbf{x}(0), t) \delta \mathbf{x}(0)
$$

となる. 行列 $\mathrm{L}(\mathrm{x}(0), t)$ の各要素は次の式から 求められる.

$$
\mathrm{L}_{\mathrm{ij}}(\mathbf{x}(0), t)=\exp \left[\int_{0}^{t} \mathrm{~J}_{i j}\left(t^{\prime}\right) d t^{\prime}\right]
$$

ただし $, i, j$ は行列の要素番号 $(i, j)$ を表してい る.

リアプノフ指数は次のように定義する.

$$
\lambda_{i}=\lim _{t \rightarrow \infty}(1 / t) \ln \left|\chi_{i}(t)\right|
$$

ここで, $\chi_{i}(t)$ は行列 $\mathrm{L}(\mathrm{x}(0), \mathrm{t})$ の固有值であ る $(i=1,2, \cdots, m)$.

以上のリアプノフ指数の求め方は近接軌道が指 定できる場合, 即ち相空間の軌道 X $(\mathrm{t})$ が微分方

程式 $\dot{X}=F(X)$ の形に書ける場合の方法である. 放 電点分布のような微分方程式が未知の場合には, まず 5.1 節の方法で $\mathrm{m}$ 次元相空間のアトラクタを 構成する. そして, 相空間にある点 $\boldsymbol{x}_{j}$ の近くの点 の集団 $\boldsymbol{x}_{i}$ ( $i$ は任意)を選び，適当な時間ステップ $k$ 後の $\boldsymbol{x}_{j+k}$ と $\boldsymbol{x}_{i+k}$ から $\delta \boldsymbol{x}_{i}=\boldsymbol{x}_{i}-\boldsymbol{x}_{j}, \delta \boldsymbol{x}_{i+k}=\boldsymbol{x}_{i+k}$ 一 $\boldsymbol{x}_{j+k}$ を得る. $\delta \boldsymbol{x}_{i}$ と $\delta \boldsymbol{x}_{i+k}$ を式 (2) の各々 $\delta \mathrm{X}(0)$ と $\delta \mathrm{X}(\mathrm{t})$ に代入し, 行列 $\mathrm{L}(\mathrm{x}(0), \mathrm{k})$ を最小自乗法 により決定する.こうして得られた行列 L $((x)$ ， k)の固有值を計算し, 式 (6)に代入すれば, リアプ ノフ指数 $\lambda_{i}(i=1,2, \cdots, m)$ を計算できる. このとき 


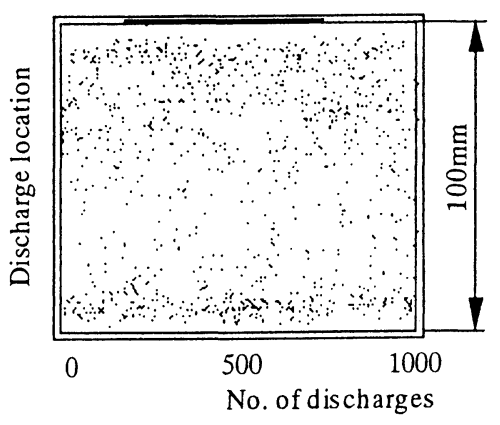

Fig. 7 Example of distribution of discharge locations (stable state)

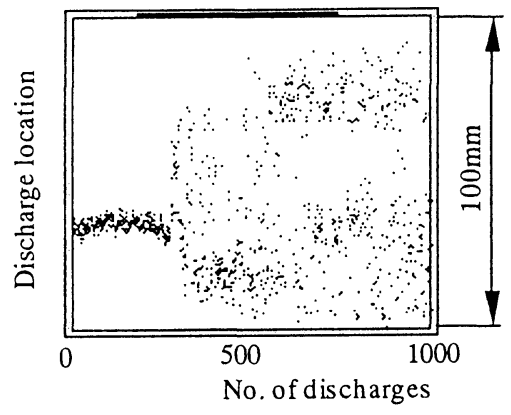

Fig. 8 Example of distribution of $d$ is charge locations (unstable state)

リアプノフ指数 $\lambda$, が一つでも正であれば系はカ オス的である ${ }^{10)}$.

図 3 に示すような放電点分布データからリアプ ノフ指数を計算した結果を図 6 に示す.リアプノ フ指数 $\lambda_{1}$ が約 0.8 であり, 正の值であることか ら，図 3 の放電点分布がカオス的であることを証 明できた。

\section{7. 制御への応用に間する考察}

図 7,8,9 は休止時間が $20 \mu \mathrm{s}$ のとき得られた安 定性の異なる 3 種類の放電点分布データである. これらのデータに対して，5.2 節の方法で相関次 元と埋め込み次元の関係を求めた結果が図 10 で ある. 図7のような安定な放電状態のアトラクタ 次元が，図 8,9 のような不安定な放電状態よりか なり大きいので，アトラクタ次元と放電状態の間 に強い相関があることが分かった．

図 7,8,9 は一目で安定不安定が認識できる場合 の例であるが，次に一見して安定か不安定か判断

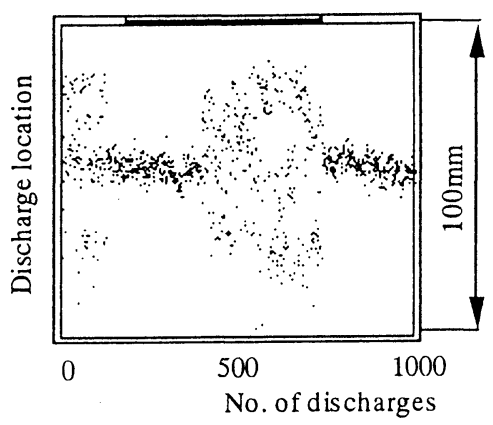

Fig. 9 Example of distribution of dis charge locations (unstable state)

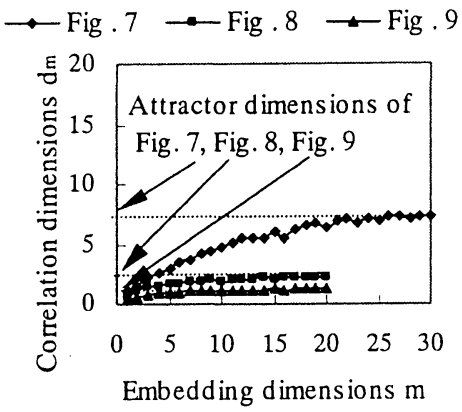

Fig. 10 Attractor dimensions in distributions of Figs. 7, 8 and 9

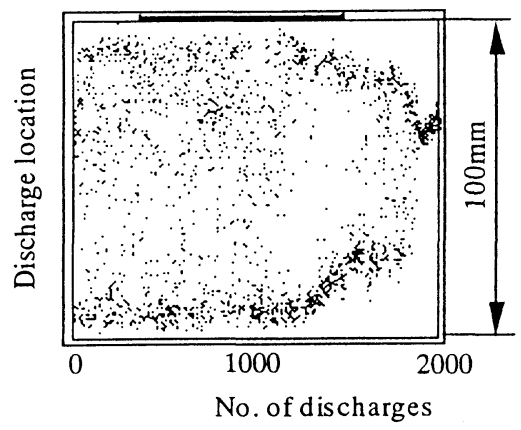

Fig. 11 Example of distribution of discharge locations $\left(t_{0}=20 \mu \mathrm{s}\right)$

が困難な 2 種類の放電点分布についてアトラクタ 次元を求めてみた。図 11 は休止時間が $20 \mu \mathrm{s}$ 時の 放電点分布の一例であり, 最初の 1000 回の放電中 は加工が安定に進行しており, その後加工が偏在 し不安定な状態に移った。 また, 図 12 は休止時間 が $80 \mu \mathrm{s}$ 時の放電点分布の一例であり, 最初の 


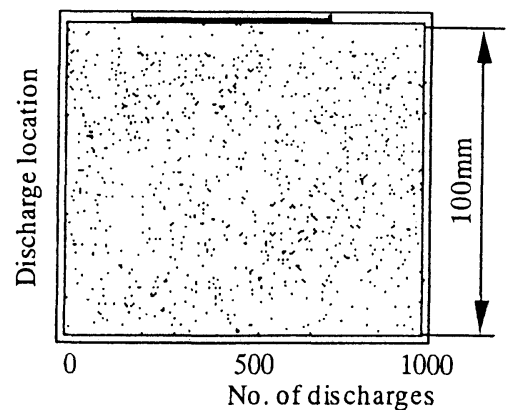

Fig. 16 Distribution of discharge locations with AC combined pulse line
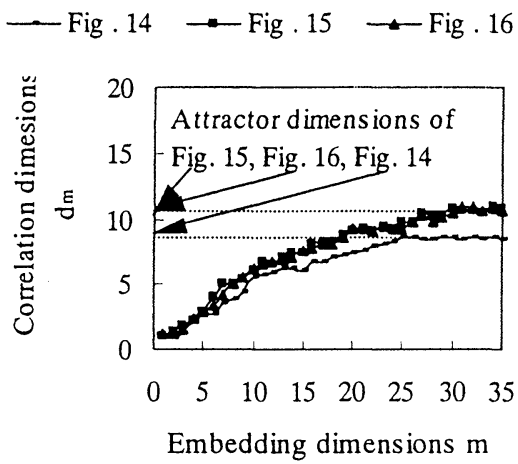

Fig. 17 Attractor dimensions in distributions of Figs. 14, 15 and 16

\section{8. 放要点探索アルコリスムムよる放電点分布の カオス性の考察}

放電加工の放電点分布はカオスであること，つ まり, 放電位置が簡単な規則に基づき決定されて おり, 放電位置の分布はカオスの様相を呈するこ とから，放電点探索による放電加工のシミュレー ションが可能であることを意味している. Kunieda $ら^{576)}$ は 1 ) ギャップが狭く加工屑濃度が高い点の 探索による放電点の決定，2）工作物と工具電極 の除去，3）加工屑の発生と移動，4）工具電極 の送り，のような単純なルーチンの繰り返しで放 電加エのシミュレーションを行っている. このシ ミュレーション方法を用いて, $18 \mathrm{~mm} \times 18 \mathrm{~mm}$ の工具 電極と同じ断面を持つ工作物を加工したシミュレ ーションを行い, シミュレーションが定常状態に 入った時の放電点分布を求めた結果を図 18 に示 す．ここで横軸は放電回数であり，縦軸は放電面 上に設定された $\mathrm{x}, \mathrm{y}$ 座標上での放電位置の $\mathrm{y}$ 座標

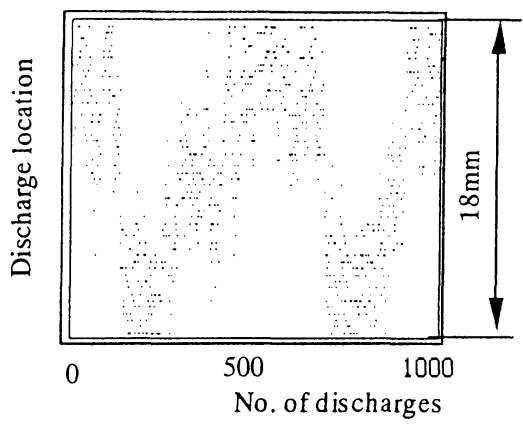

Fig. 18 Distribution of discharge locations of simulation without using random number

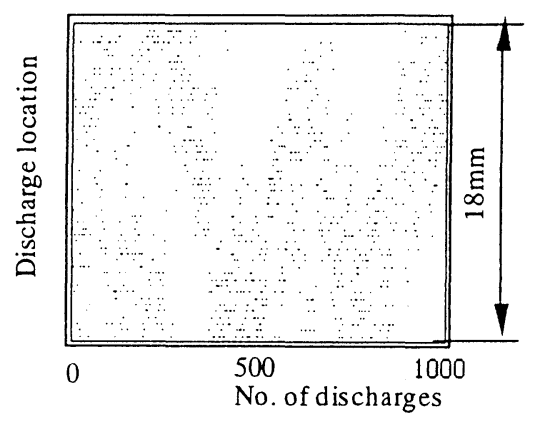

Fig. 19 Distribution of discharge locations of simulation using random number

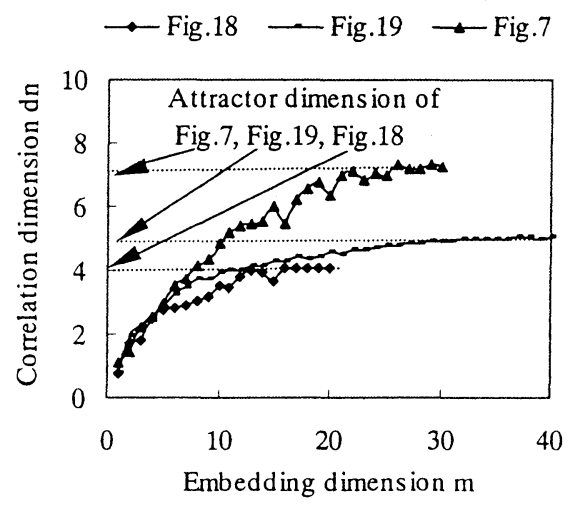

Fig. 20 Attractor dimensions of simulation

である. 一方で, 滝田ら ${ }^{133}$ は放電の確率過程を考 慮し, 乱数を導入したシミュレーションも行って いる.つまり，上記のシミュレーションのルーチ 


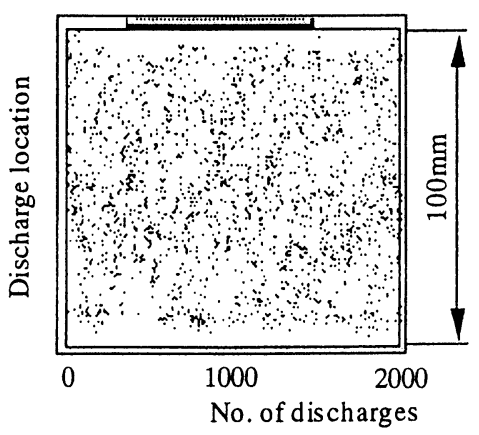

Fig. 12 Example of distribution of discharge locations $\left(\mathrm{t}_{0}=80 \mu \mathrm{s}\right)$

1000 回だけではなくその後も加工

がずっと安定に進行している，そこで，一見安定 に見える図 11,12 の最初の 1000 回の放電点分布の アトラクタ次元を求める.図 13 にその結果を示す. この結果より, 図 11 の最初の 1000 回のアトラク 夕次元は図 12 のアトラクタ次元より低い,つまり 図 11 の最初の 1000 回が図 12 よりカオスの程度が 弱いことが分かった．このことより，放電点分布 のアトラクタ次元から放電状態の安定性を判別で き, 特に異常放電の前駆現象を把握する方法とし て応用の可能性が高いと考えられる.

別の例として筆者ら ${ }^{12)}$ は幅が狭くピークが高い 電流パルスの中に幅が長くピークが低い電流パル スを混入する異種パルス混合加工法を開発し，そ れにより高速な加工が可能であることを示したが, その高速化の原因については未解明であった。 そ こで, 異種パルス混合と混合しない時の放電点分 布のアトラクタ次元を調べてみた. 図 14 にはパル ス混合しない時の放電点分布, 図 15 には単極異種 パルス混合時の放電点分布, 図 16 には両極異種パ ルス混合時の放電点分布のデータを示す.これら の放電点分布のアトラクタ次元を求めた結果を図 17 に示す.この結果より, 異種パルス混合時の放 電点分布のアトラク夕次元が混合しない時と比べ 大きいことがわかった，つまり，異種パルス混合 より系の自由度が増加し, 放電点分布がより強い カオスに移り変わることによって系全体が安定状 態に移行したので加工速度が増加したと考えられ る. 今までの異種パルス混合は 2 種類のパルスだ けの混合であったが，さらに多くの種類のパルス

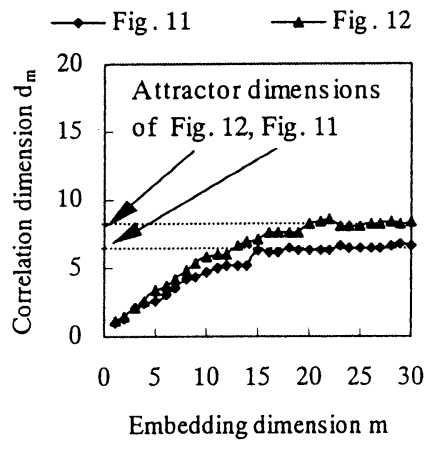

Fig. 13 Attractor dimensions in distributions of Figs. 11 and 12

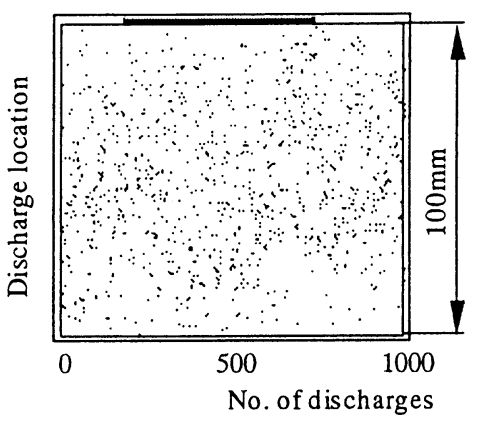

Fig. 14 Distribution of discharge locations without using combined pulse line

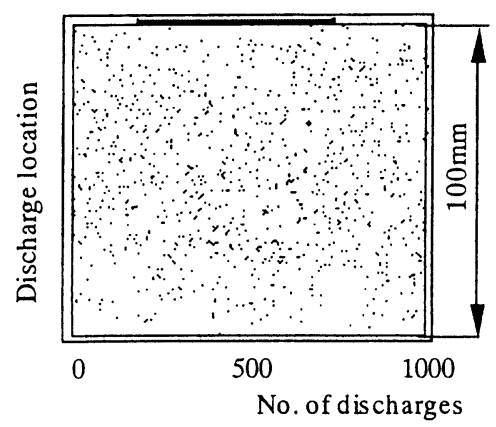

Fig. 15 Distribution of discharge locations with DC combined pulse line

を混合することによって系全体がランダム状態に 近づくので，さらに高速な加工が行えると考えら れる. 
ンの中の放電点決定の過程において, ギャップが 狭く加工屑濃度が高いほど值が大きくなるように 構成された評価関数に乱数をかけた值を新たな評 価関数と定義して放電点を決定している. そのシ ミュレーションの放電点分布を図 19 に示す.ここ で, 図 18 と図 19 の放電点分布についてアトラク 夕次元を計算した結果を図 20 に示す.また, 参考 のため, 実際の放電点分布（図 7）のアトラクタ 次元の結果も図 20 に示している. 確率過程を考慮 したシミュレーションの放電点分布のアトラクタ 次元は確率過程を考慮していないシミュレーショ ンの放電点分布のアトラクタ次元より高いことが わかった. しかし，実際の放電加工の放電点分布 のアトラクタ次元と比べ, 確率過程を考慮したシ ミュレーションの放電点分布のアトラクタ次元は まだ低過ぎることもわかった，つまり，確率過程 を考慮したシミュレーションでは乱数が支配する 程度が現実の加工より低いので, 実際の放電加工 現象をシミュレーションするには, 乱数的な要素 を強め, 系の自由度を増やせば, シミュレーショ ンが可能と考えられる.

\section{9. 結論}

カオス理論を用いて放電点分布を解析し, 次の ようなことが分かった.

1)放電加工の放電点分布はカオス的である.

2) 放電点分布のアトラクタ次元から放電状態の安 定・不安定の識別ができる.

3) 放電点分布が強いカオス状態になるほど加工が 安定し高速な加工を行える.

4)放電点分布を強いカオス状態にする一つの手段 としては，異なるパルスを混合する方法が有効 である.

5）放電点分布のカオス性により放電点探索アルゴ リズムによる放電加工のシミュレーションが可 能である.また, 確率過程を考慮したシミュレ ーションは, ギャップ分布と加工屑濃度分布か ら決定論的に放電位置が決まると考えたモデル より実際の放電現象を正確に表現している.

\section{参考文献}

1) M.Kunieda, H.Kojima: On-Line Detection of EDM Spark Location by Multiple Connection of Branched Electric Wires, Annals of the CIRP, 39, 1, 177 (1990)

2) H.Kojima, M.Kunieda, N.Nishiwaki: Understanding Discharge Location Movements During EDM, Proc. of ISEM-X, 144 (1992)

3) 小原, 奥山, 米屋, 井岡 : 放電加工の放電位置検出 に関する研究（第 2 報），電気加工学会誌，Vol.24， No.47, 12 (1992)

4) N.Mohri, K.Tanaka, M.Suzuki, K.Furutani: Detection of Discharge Dispersion in Electrical Discharge Machining, Proceedings of 3 rd International Conference on Die \& Mould Technology, Taipei, Taiwan, 341 (1995)

5) M.Kunieda, M.Kiyohara: Simulation of Die-Sinking EDM by Discharge Location Searching Algorithm, IJEM, No. 3, 79 (1998)

6) M.Kunieda, W.Kowaguchi, T.Takita: Reverse Simulation of Die-Sinking EDM, Annals of the CIRP, Vol.48, 115 (1999)

7）長島：カオスをとらえる,日本物理学会誌, 41,19 (1986)

8）長島, 馬場 : カオス入門, 培風館 (1993)

9）下條：カオスカ学入門, 近代科学社（1992）

10) M.Sano and Y.Sawada : Measurement of the Lyapunov Spectrum from a Chaostic Time Series, Phys. Rev. Lett. 55,1082 (1985)

11) J.P.Eckmann, S.O.Kamphorst, D.Ruelle and S.Ciliberto: Liapunov Exponents from Time Series, Phys. Rev. A34, 4971 (1986)

12）韓, 国枝: 異種パルス混合による鋼の高速低消耗 加工, 精密工学会秋季大会学術講演会講演論文 集, 419 (1999)

13）槞田, 国枝: 放電点探索アルゴリズムを用いた形彫 り放電加工における放電集中のシミュレーション, 電気加工全国大会講演論文集, 3（1999）

(2000 年 7 月 21 日受付) 